\title{
Linguistic Landscape of the Names and Cultural Values of Rumah Makan Minang
}

\author{
Oktavianus \\ Fakuculty of Humanities \\ Andalas University \\ Indonesia \\ oktavianus@fsastra.unand.ac.id
}

\author{
Khairil Anwar \\ Faculty of Humanities \\ Andalas University \\ Indonesia \\ khan_msi@yahoo.co.id
}

\author{
Ike Revita \\ Faculty of Humanities \\ Andalas University \\ Indonesia \\ Revita_ike@yahoo.com
}

\begin{abstract}
Rumah Makan Minang (RM Minang) is well known across Indonesia and even abroad. It can easily be found everywhere in the city and even in a small town. The linguistic landscape of the names of RM Minang is interesting to study. Besides, the various names of RM Minang also contain Minangkabau cultural values. This research is an attempt to investigate how the names of RM Minang are created and cultural values behind them are reflected. The data for this study are taken from the names of RM Minang located in Sumatera, Java, Bali and Lombok. The study is done from the perspective of linguistic landscape-an approach used to portrait how language is used and designed in public spaces. The result of analysis indicates that linguistic landscape of RM Minang is diversity of names and cultural values. The names of RM Minang and cultural values behind them vary largely. The names of RM Minang are derived from nick name of Minangkabau people, part of body related to eating activity, plants, taste, places, place of origin, expectation and blessing from the parents and family. Among cultural values reflected in the names of RM Minang are unanimous, loyality, and togetherness.
\end{abstract}

\section{Keywords- Linguistic landscape, name, rumah makan Minang, and cultural values}

\section{INTRODUCTION}

Language plays an important role in the life of human beings. Language exists and occurs around us in public spaces. Language is not only functioned as tool of communication but also used to build the life of its speaker in all aspects. The nature of language can be seen from different perspectives. The research done by linguists developed rapidly. The linguists have done the research both in the level of microlinguistics and macrolinguistics, comparative study, and applied linguistics.

One of the approaches used and developed in looking at how language is used in public spaces is linguistic landscape which is abbreviated as LL. The complexity of human life at this time triggered the occurance of the variation of language both in the spoken and written forms. Written language occured in many public spaces. One of them is the names of RM Minang.

RM Minang, which is also called Rumah Makan Padang, is very famous. RM Minang has business, cultural and aesthetic dimensions. In terms of business dimensions, RM Minang is the the source of income for not only Minang people but also for other people working in RM Minang across Indonesia. In terms of cultural dimensions, RM Minang reflects Minangkabau cultural identity in terms of food. Minang food which is also called Padang food is famous for its rich taste of succulent coconut milk and spicy chili. The term Masakan Padang 'Padang food' is very famous across Indonesia. It designates the cullinar from all parts of Minangkabau. CNN (2011) even exposed that randang 'spicy meat stew' is the delicious food in the world. In terms of aesthetic dimensions, the dishes are put on a display in high-stacked plates in the window of RM Minang orderly so people can see them easily. The name of RM Minang is attached and pasted in front of food display. The naming process of RM Minang is closely related to business, cultural and aesthetic aspects.

The business of RM Minang is aimed at empowering the economy of Minangkabau people and those who worked there. Thus, RM Minang can be found in the cities and villages across Indonesia. RM Minang in rantau or outside of West Sumatera is closely related to temporary migration concept of Minangkabau people (Naim, 1984) and work ethic of Minangkabau people (Amir, 1997). Empowering the economy of Minangkabau people through RM Minang can be done only if RM Minang can survive. Promotion is the key factor. The name of RM Minang can be regarded as one of the promotion of RM Minang. RM Minang is identified through its names. Therefore, this short writing is an attempt to discuss how the names of RM Minang is created and how cultural value is reflected through the names.

\section{THEORETICAL REVIEW}

The word landscape is related to natural view. KBBI (1998) defined landscape as (1) tata ruang di luar gedung (untuk mengatur pemandangan alam); (2) jumlah total aspek setiap daerah baik pedesaan maupun kota. The concept of landscape for natural view is adopted to portrait the view or landscape of language use in a public spaces so that the term linguistic landscape is used as an approach to do research on language. Related to definition of linguistic landscape, Landry and Bourhis (1977:25) stated that the language of public road signs, advertising billboards, street names, place names, commercial shop signs, and public signs on government buildings combines to form the LL of a given territory, region, or urban agglomeration" (Landry and Bourhis 1997:25). Gorter (2006c:1) stated that linguistic landscape is an approach used to describe language situation of one region or 
public space. Then, the linguistic landscape of one public space or territory can serve two basic functions namely informational and symbolic functions (Landry \& Bourhis, 1997: 25).

Research on linguistic landscape has much been done. Two of them is mentioned in this writing. Colluzi (2012) for examples, did the research on linguistic landscape in Brunai Darussalam. The result of the research indicates that there is a high variaion of language used in Brunai Darusssalam namely Malay, English and Chinese language. English is regarded as high prestige language. Amer (2014) did research on LL of the names of shops in Aqaba Jordania. The result of the research indicates that the names and labels of the shop uses Arabic language and English. English is used to attract the attention of people. English is used because it is the language of globalization, modernity, and prestige.

\section{METHOD}

It is a qualitative study with the combination of library and field research. The data for this study are the names of RM Minang collected in Sumatera, Java, Bali and Lombok. Data are collected by photographing the names of RM Minang. Then, the information related the names and values of the names of RM Minang is also collected by interviewing the owners, the waiters and the customers of RM Minang. The analysis of data is done by applying referential and pragmatic identity methods in which the names and the values are analyzed by referring to context where RM Minang is located.

\section{A. The Names of Rumah Makan Minang}

\section{FINDING AND DISCUSSION}

RM Minang is very famous. It can be found almost everywhere in cities and villages in Indonesia. The size of RM Minang varies from small shop in the street and big restaurant. One interesting aspects related to RM Minang is the use of language as the names and labels of RM Minang. The study of LL RM Minang is done by Oktavianus, dkk (2016 dan 2017). Some of the examples of the names of RM Minang can be seen in the Table 1 below.

\begin{tabular}{|c|c|c|c|}
\hline No & SOURCE & NAME & LOCATION \\
\hline \multirow[t]{11}{*}{1} & \multirow[t]{11}{*}{ Name of Place } & RM BUKITTINGGI & Malaka \\
\hline & & RM NGARAI SIANOK & Jakarta \\
\hline & & RM PINCURAN TUJUAH & Jakarta \\
\hline & & RM DANAU DI ATAS & Lampung \\
\hline & & RM PARIAMAN & Jakarta \\
\hline & & RM PADANG RAYA & Jawa Tengah \\
\hline & & RM PARIS JAYA & Jawa Tengah \\
\hline & & RM RANAH MINANG & Manado \\
\hline & & RM SENAYAN CITY & Jakarta \\
\hline & & RM SUNGAI KALU & Solok Selatan \\
\hline & & RM INDARUNG RAYA & Padang \\
\hline \multirow[t]{6}{*}{2} & \multirow[t]{6}{*}{ Taste } & RM LIDAH BAGOYANG & Kota Padang \\
\hline & & RM GOYANG LIDAH & Kota Padang \\
\hline & & RM SALERO KAMPUANG & Kota Padang \\
\hline & & RM SALERO KITO & Kota Padang \\
\hline & & RM PONDOK SALERO & Kota Padang \\
\hline & & NP SALERO SEPAKAT & Jakarta \\
\hline \multirow[t]{4}{*}{3} & \multirow[t]{2}{*}{ Name of $S u k u$} & RM SIKUMBANG & Jakarta \\
\hline & & RM CHANIAGO & Jakarta \\
\hline & & RM PUTRA JAMBAK & Cirebon \\
\hline & & RM PUTRA TANJUNG & Cirebon \\
\hline \multirow[t]{6}{*}{4} & Nickname & RM PAK DATUAK & Padang Panjang \\
\hline & & RM IBUK & Padang \\
\hline & & RM MAMA & Padang \\
\hline & & RM ACIAK & Padang \\
\hline & & WP UPIK & Samarinda \\
\hline & & RM MINTUO & Solok \\
\hline
\end{tabular}




\begin{tabular}{|c|c|c|c|}
\hline & & & \\
\hline \multirow[t]{8}{*}{5} & \multirow[t]{8}{*}{ Name of Plant } & RM SATAMPANG BANIAH & Jakarta \\
\hline & & RM BAREH SOLOK & Jakarta \\
\hline & & RM PADI SALIBU & Jakarta \\
\hline & & RM PADI RIMBUN & Padang \\
\hline & & RM TALANG SARUMPUN & Padang \\
\hline & & RM BUNGO INDAH & Bali \\
\hline & & RM SARI RASO & Bali \\
\hline & & PM PAUAH SABATANG & Batusangkar \\
\hline \multirow[t]{6}{*}{6} & \multirow{6}{*}{$\begin{array}{l}\text { Positive } \\
\text { connotative concept }\end{array}$} & RM BAHAGIA & Padang \\
\hline & & RM MINANG SAIYO & Jakarta \\
\hline & & RM SEPAKAT & Padang \\
\hline & & RM IDOLA MINANG & Jawa tengah \\
\hline & & RM SINAR MINANG & Jakarta \\
\hline & & RM TUAH SAKATO & Bali \\
\hline 7 & Place of origin & RM ASANO & Lombok \\
\hline \multirow[t]{2}{*}{8} & Price Information & RM MINANG MURAH & Nusa Dua Bali \\
\hline & \multicolumn{2}{|c|}{ Source: Oktavianus and Khairil Anwar, 2016 dan 2017} & \\
\hline
\end{tabular}

Human beings communicate by using sign and configuration of signs. Signs used to express all aspects of human life can be devided into two types namely linguistic and nonlinguistic signs. Linguistic signs form spoken and written language. Nonlinguistic signs form body language and nonbody language. Nonbody language delivers message through pictures. Signs and configuration of signs in written language can be in the form word, frase, and sentence. Types signs can be seen in the figure 1 below.

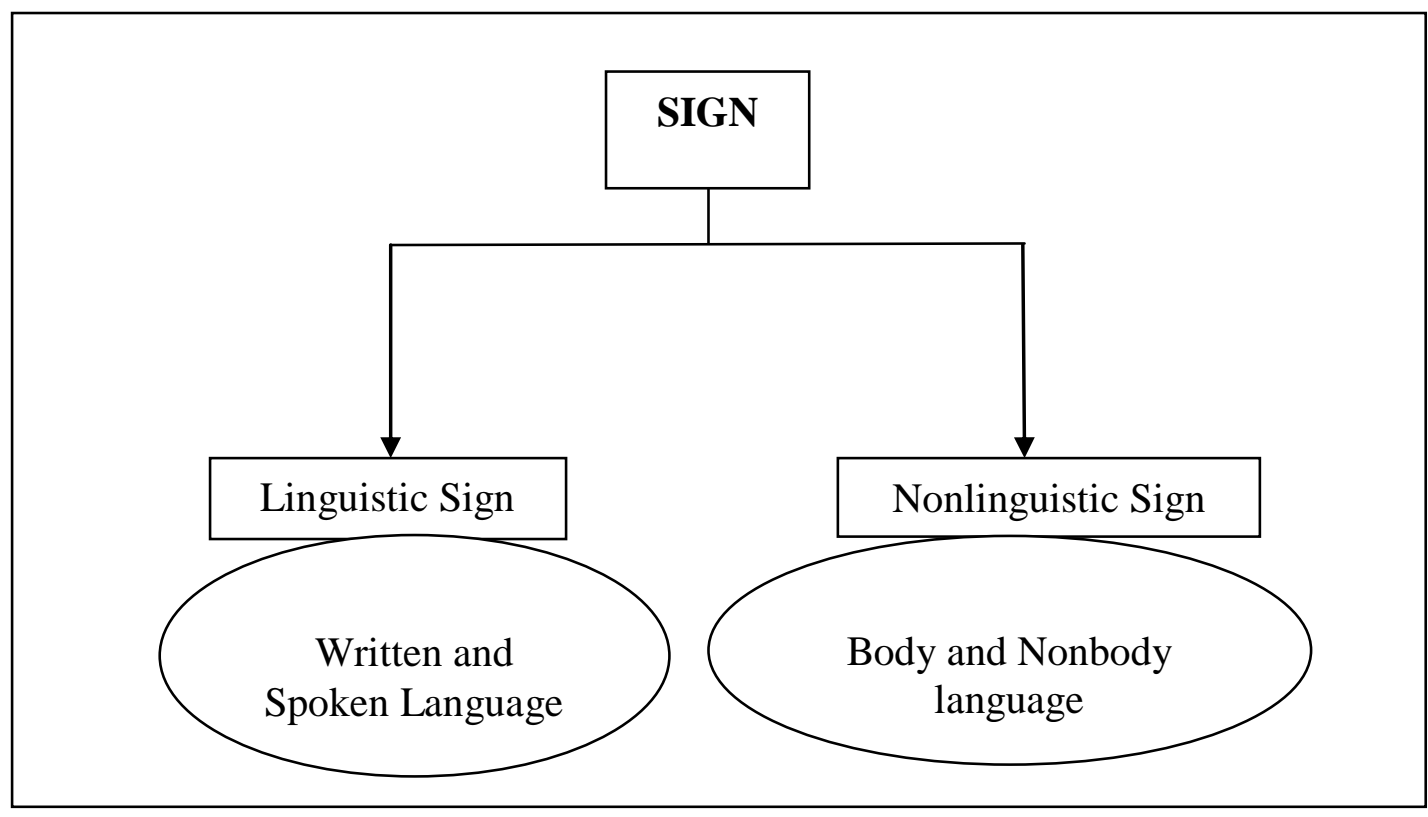

Fig. 1. Types signs

Naming process of RM Minang is very dynamic. The names of RM Minang is taken from anything that inspires the owner of RM Minang, something impressive, the enjoyable things, events, wishes and expectation. The names of RM Minang are also derived from something having close emotional relationship with the owner of RM Minang; positive concept of local culture; word related to rice; the names of menu; and certain parts of body related to eating activity.

The names of RM Minang is constructed by using signs. From semiotic perspectives, for examples, Ferdinand de Sausure stated that language can be constructed through sign and sign system. Sign is the combination between signifier and signified. De 
Saussure stated that the relationship between signifier and signified is arbitrary. The relationship between sign and its user form a complex network. There is the process of semiosis namely any form of activity that involves signs. Charles William Morris (1901-1979) stated that there are three dimensions of semiosis namely syntactic dimensions (relation among signs), semantic dimensions (relation between sign and its object), and pragmatic dimensions (relation between sign and its interpreter).

If language is used by its speaker, word, phrase and sentence will function or perform a text. Text can be easily found in public spaces. Text is attached or pasted to RM Minang as the names and labels. The landscape of the texts as the names and labels of RM Minang varies in term of the number of words used, graphic designs, colour and lay out. In terms of the types of sign used, the LL of the name of RM Minang is created in two ways. First, names of RM Minang are constructed by using linguistic signs. This types of name can be seen in figure 2 below.

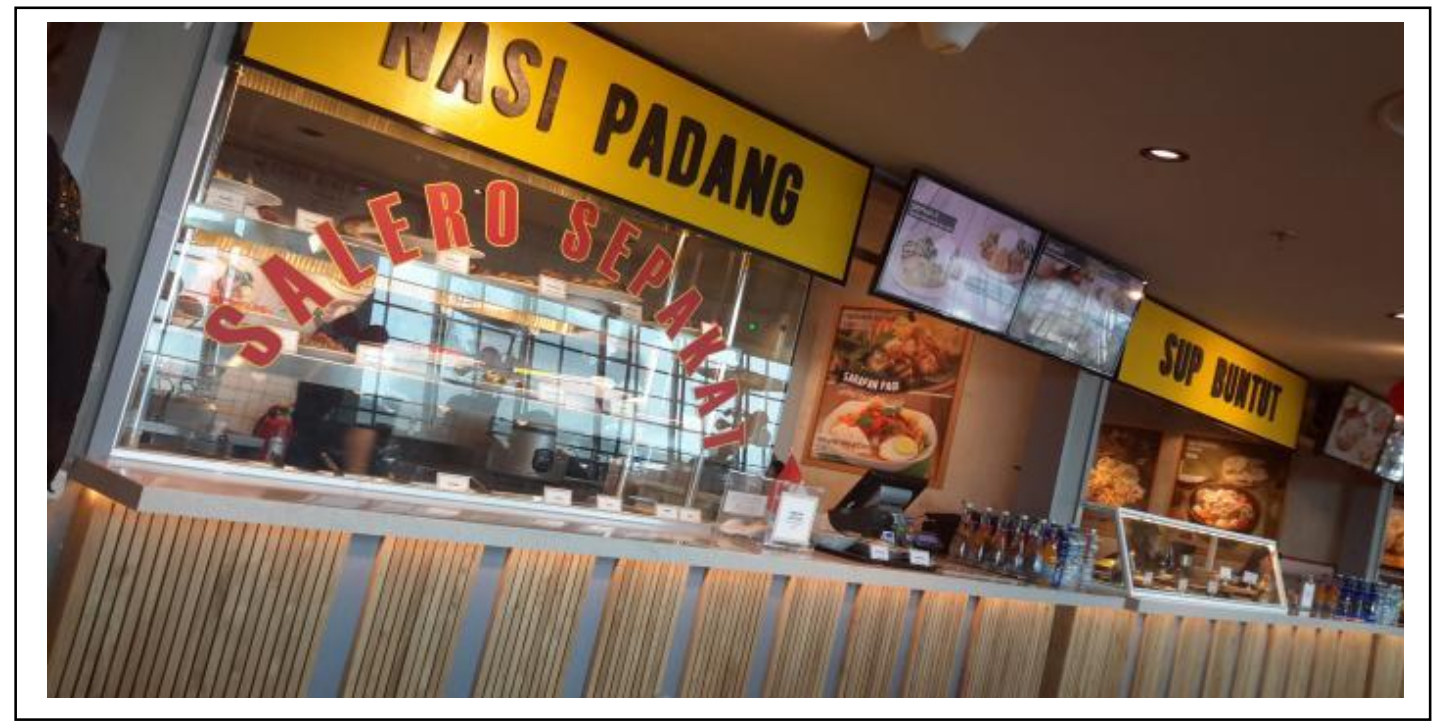

Fig. 2. NASI PADANG : SALERO SEPAKAT in Jakarta (Dok. Oktavianus)

The above picture is the name of one of RM Minang in Jakarta. The text is constructed by using linguistic signs. Its LL is the phrase NASI PADANG written in black capital letters as the marker of RM Minang. SALERO SEPAKAT is warped and written in red capital letters. In terms of graphic design, linguistic signs as the element of text is attached and pasted on the background with sharp colour so that it is easy to view it from far distance. The language used as the marker of RM Minang varies such as MASAKAN PADANG, WARUNG NASI PADANG, RUMAH MAKAN PADANG, and RESTORAN. The phrase MASAKAN PADANG, WARUNG NASI PADANG and RUMAH MAKAN PADANG are dominantly used. The word restoran is used by RM SEDERHANA in Bintaro namely RESTORAN SEDERHANA BINTARO in Jakarta. The use of label of RUMAH MAKAN can be seen in the figure 3 . below.

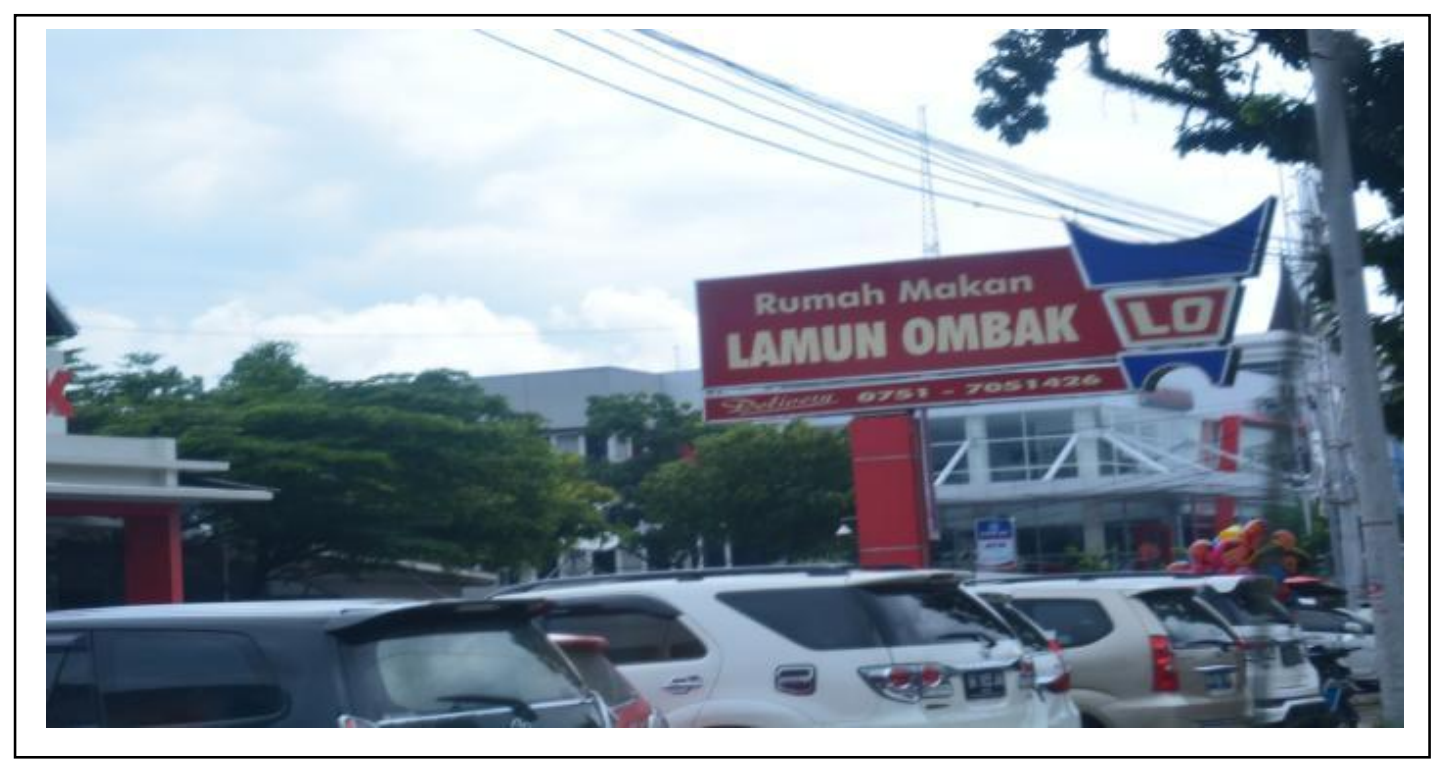


Fig. 3. RM LAMUN OMBAK in Padang (Dok. Oktavianus).

Second, text which is constructed by using the combination between linguistic and nonlinguistic signs. RM Minang contains text of this category. In a text constructed by using combination between linguistic and nonlinguisitic signs, these two kinds of signs will collaborate to each other to support the delivering of message to public. One of the examples of the name of RM Minang can be seen in the figure 4 below.

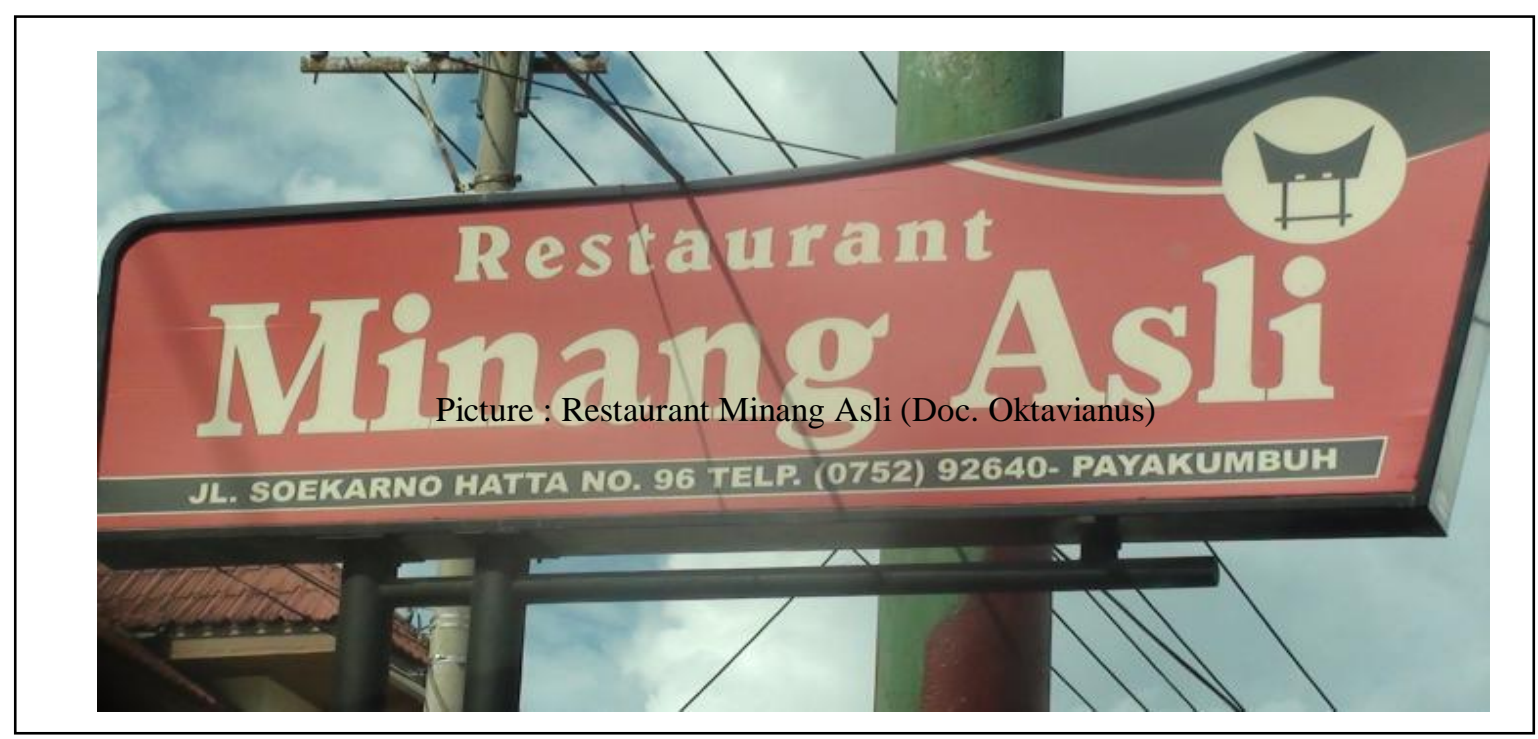

Fig. 4. Restaurant Minang Asli in Padang (Dok. Oktavianus).

LL of the names of RM Minang in the above picture is code-mixing between Indonesian and English. The name of RM is Minang Asli. The background in which the name is attacked or pasted is painted red. The choice of this types of colour is done in order name plank can be seen from far distance. It becomes the center of attention. Nonlinguistic sign used here is the symbol of Rumah Adat Minang in the top right of the plank. Thus, the name Restaurant Minang Asli and the symbol of Rumah Adat Minang collaborate to each other to support and strengthen the delivery of message and identity that RM belongs to Minang people.

Third, text which is only in the form of picture. RM Minang usually puts the picture of Rumah Adat Minang, natural view as the place of the origin of RM Minang, and the picture of food served. Below is the example of nonlinguistic text. The example can be seen in the figure 5 below.

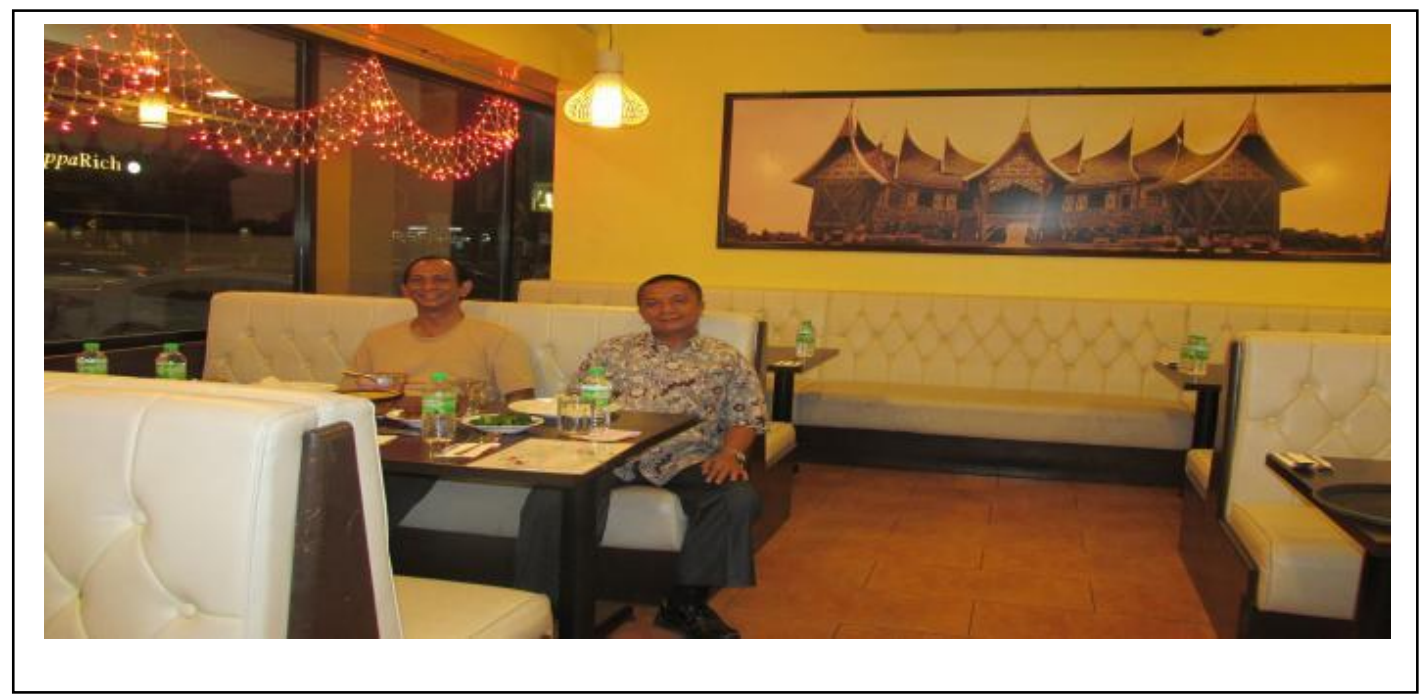

Fig. 5. Restaurant Minang Asli in Padang (Dok. Oktavianus). 
The above picture is the interior of RM SARI RATU in Kuala Lumpur. The picture of Rumah Adat Minang is pasted on the wall of rumah makan not as the names of rumah makan but as Minangkabau cutural identity. Although the name of RM SARI RATU is written in Indonesian language, by looking at the picture of Rumah Adat Minang, people can identify that RM SARI RATU may belong to people from Minangkabau

\section{B. Cultural Values in The Names of Rumah Minang}

Names are more than a word or set of words by which a person or things is known, addressed or referred to (Hornby AS, 1983:559). Names embody value or cultural values. Cultural values can be defined as the norms or markers of what is good and bad, acceptable and unacceptable, important and unimportant in a community. How the names reflects cultural value can be seen in the figure 6 below.

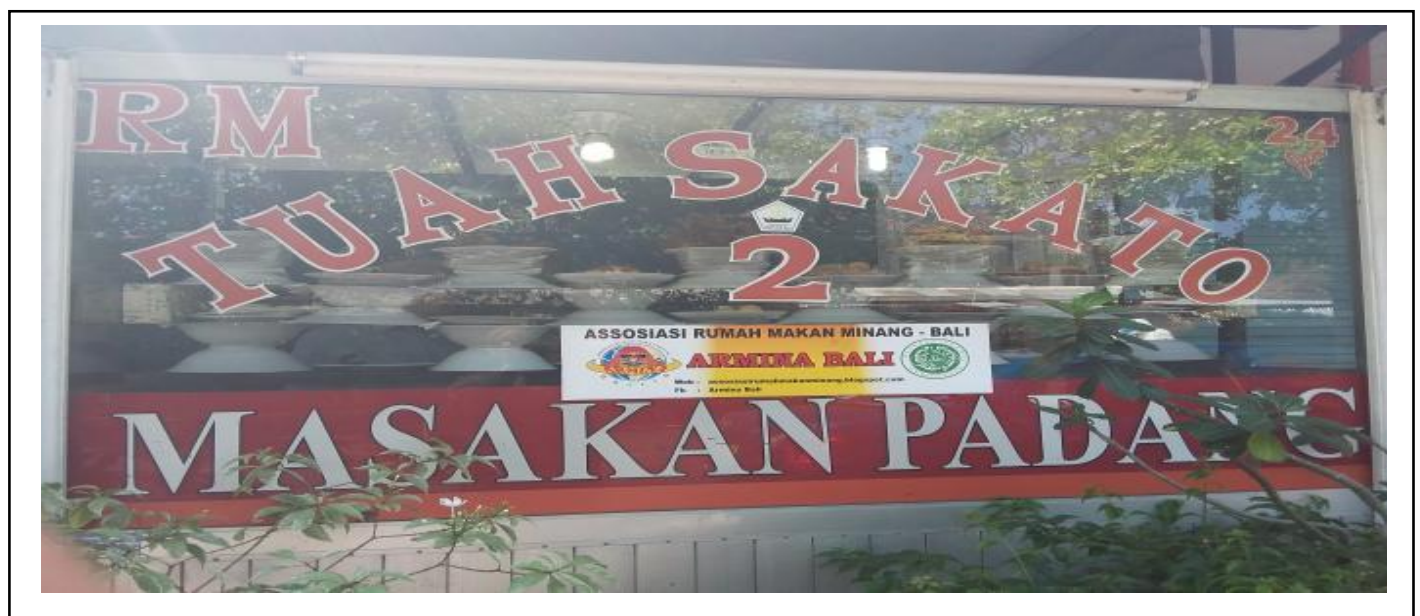

Fig. 6. RM TUAH SAKATO di Denpasar (Dok. Oktavianus)

Tuah Sakato is the motto in Minangkabau culture which means united and prosperous. It is put as the name of RM Minang. It is related to Indonesian proverbs, bersatu kita teguh, bercerai kita runtuh 'united we stand, devided we fall'. Colaboration in doing something is very important in life. Unity is very crucial in running the business of RM Minang. The other similar names of RM Minang is RM MINANG SAKATO (Denpasar), RM MINANG SAIYO (Bogor), RM MINANG SAIYO SAKATO (Medan). In Minangkabau language, the word saiyo, sakato, and sepakat is equivalent to seia, sekata, and sepakat in Indonesian language which is also equivalent to unanimous in English.

The other cultural values that can be seen in the names of RM Minang is prayer, expectation and blessing. Prayer, hope and blessing from the parents or core family are attached and pasted as the names of RM Minang as in the figure 7 below.

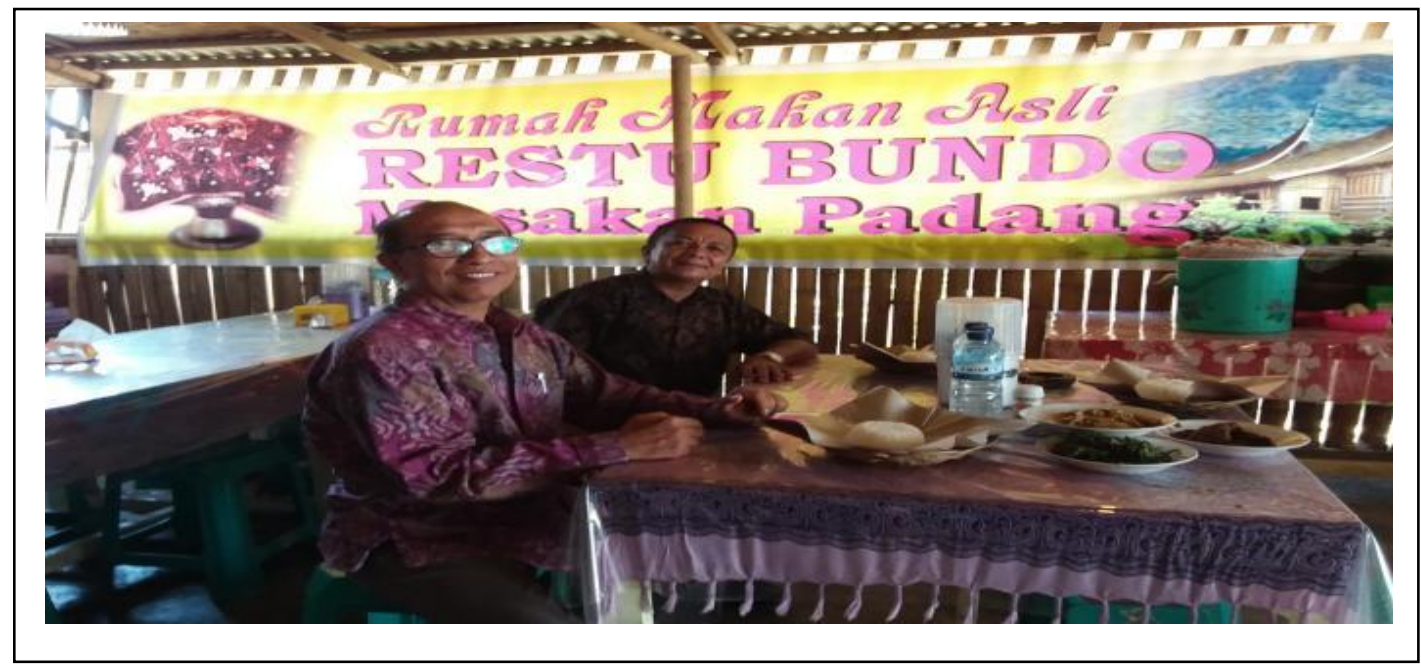

Fig. 7. RM TUAH SAKATO di Denpasar (Dok. Oktavianus) 
It is common that when Minangkabau people wants to go to rantau 'temporary migration place', they expect prayer and blessing from the parents and other family. The prayer and blessing are enshrined as the name of rumah makan.

It is possible in life that someone do good deeds to others. For Minangkabau people, this benevolence is perpetuated as the name of rumah makan. Thus, there is RM JASO MINTUO 'mother's service or help' (Padang), RM JASO MANDE 'mother's service or help' (East Java), RM JASO BUNDO 'mother's service or help' (Jakarta), RM JASO AYAH 'father's service or help' (North Sumatera) and RM JASO KAWAN 'friend's service or help' (Purbalingga East Java). Naming process of this kind shows that Minang people are not easy to forget someone's goodness.

\section{CONCLUSION}

At the end of this writing, it can be concluded that there are two types of name designs of RM Minang. First, the name of RM Minang is constructed by using linguistic signs only. Second, the most common one is that the name of RM Minang is constructed by using combination between linguistic nonlinguistic signs. The series of language used as the names of RM Minang are Minangkabau language, Indonesian language and foreign language namely Arabic and English language. The names of RM Minang always contain cultural values and identity markers. Cultural values reflected in the names of RM Minang as unanimous, loyality, and togetherness. The identity markers are the use of Minangkabau language, the picture of Rumah Adat Minang, and the label of Rumah Makan Padang, Masakan Padang, Warung Nasi Padang and Masakan (Khas) Minang.

\section{References}

Amer, Faten \& Rasha Obeidat. 2014. Linguistic Landscape: A Case Study of Shop Signs in Aqaba City, Jordan. Asian Social Science; Volumea. 10, Nomor. 18.

Coluzzi, Paolo. 2012. The Linguisitic landscape of Brunai Darussalam: Minority Languages and the Threshold of Literacy. Southeast of Asia: A Multidiciplinary Journal. Volume 12 Tahun 2012.

Dabbour, Khaled. 2017. "The Linguistic Landscape of Tahrir Square Protest Signs and Egyptian National Identity". Studies in Linguistics and Literature. Volume 1, Nomor. 2.

Duranti, Alesandro. 2000. Linguistic Anthropology. Cambridge: Cambridge University Press.

Foley, W. A. 1997. Antrophological Linguistics: An Introduction. Blackwell.

Gorter, Durk. 2006. Linguistic Landscape: New Approach to Multilingualism. Toronto: Multilingual Matters, Ltd.

Halliday, M.A.K, and Ruqaiya Hasan. 1980. Cohesion in English. London : Longman Ltd.

Kramsch, C. 1998. Language and Culture. Oxford : Oxford University Press.

Landry, Rodrigue \& Bourhis, Richard Y. 1997. Linguistic landscape and ethnolinguistic vitality: an empirical study. Journal of Language and Social Psychology.

Oktavianus dan Khairil Anwar. 2016. "Penamaan Rumah Makan Padang. Cerminan Hubungan Bahasa dan Budaya”. Makalah pada Seminar Kerja Sama Fakultas Ilmu Budaya Universitas Andalas dengan Akademi Pengajian Melayu, Universiti Malaya. Padang: FIB Unand.

Oktavianus. 2016. "Linguistic Landscape Rumah Makan Padang”. Makalah pada Kongres Internasional Masyakat Linguistik Indonesia. Depasar: Universitas Udayana.

Ricoeur, P. 2002. Filsafat Wacana: Membelah Makna dalam Anatomi Bahasa. (Diterjemahkan oleh Musnur Hey dari judul asli: The Interpretation Theory: Discourse and the Surplus of Meaning). Yogyakarta: Kanisius.

Schiffrin, D. 1994. Approaches to Discourse. Cambridge : Blackwell Publishers. 